This item was submitted to Loughborough's Research Repository by the author.

Items in Figshare are protected by copyright, with all rights reserved, unless otherwise indicated.

\title{
'If not me, then who?' Examining engagement with Holocaust Memorial Day commemoration in Britain
}

PLEASE CITE THE PUBLISHED VERSION

https://doi.org/10.1080/23256249.2018.1432253

\section{PUBLISHER}

Taylor and Francis @ The Institute for Holocaust Research, at the University of Haifa

\section{VERSION}

AM (Accepted Manuscript)

\section{PUBLISHER STATEMENT}

This is an Accepted Manuscript of an article published by Taylor \& Francis in Dapim: Studies on the Holocaust on 22 March 2018, available online: http://www.tandfonline.com/10.1080/23256249.2018.1432253.

\section{LICENCE}

CC BY-NC-ND 4.0

\section{REPOSITORY RECORD}

Richardson, John E.. 2019. “if Not Me, Then Who?' Examining Engagement with Holocaust Memorial Day Commemoration in Britain". figshare. https://hdl.handle.net/2134/25742. 
'If not me, then who?' Examining engagement with Holocaust Memorial Day Commemoration in Britain

John E Richardson

Loughborough University

Contact Details

John E Richardson

Department of Social Sciences,

Loughborough University

Epinal Way,

Loughborough, Leicestershire,

LE11 3TU, UK

j.e.richardson@lboro.ac.uk

$+44(0) 1509223361$

Biog

John E Richardson is a Reader in Critical Discourse Studies, Department of Social Sciences, Loughborough University. His research interests include structured social inequalities, British fascism, argumentation and multimodal commemoration. His most recent book is British Fascism: A Discourse-Historic Analysis (Stuttgart: ibidem Verlag, 2017). He is Editor of the international journal Critical Discourse Studies and co-editor of Bloomsbury book series Advances in Critical Discourse Studies. From February 2017-January 2018 he was a 
Leverhulme Trust Research Fellow, researching the ways that Holocaust Memorial Day in the UK has changed since 2002.

\section{Abstract}

This article explores what motivates ordinary people to become involved with commemorating Holocaust Memorial Day (HMD). Whilst there is an expanding academic literature on HMD, public commemoration and the memory work (and politics) of remembrance, a great deal of this commentary and analysis is offered from the first-hand perspective of academics writing about large scale public memorial or museum projects. There is, in contrast, very little published that examines small-scale public participation with HMD, including why people get involved in organising their own commemorative activities. Since 2005, the Holocaust Memorial Day Trust (HMDT) has been responsible for organising and promoting HMD commemoration in Britain and, as part of this brief, they organise free workshops across the UK for people interested in organising an activity to mark HMD. This article analyses interviews with the organisers and participants of three workshops that took place during the build up to HMD 2016. In this article, I focus in particular on the ways that interviewees orientate to questions of conscience, and the ways that their personal and political values accord with the aims of HMD. My paper suggests that pedagogic and political potentials of HMD are more varied than academic analysis has thus far suggested, and that further work is needed to explore the engagement of ordinary people in HMD commemoration.

\section{Keywords}


Holocaust Memorial Day, Commemoration, Engagement, Norm Circles, Ethnographic Discourse Analysis

\section{Introduction}

Commemorations are ongoing dynamic processes, through which narratives about the past, about 'us' and 'them' as well as beliefs and values contained in these stories, are produced and reproduced. Commemorative events play a subtle role in the garnering of public consensus, particularly at the level of values, working to consolidate myths about social ingroups and out-groups (particularly nations) and hence contributing to processes of group inclusion and exclusion. The Holocaust, in particular, has increasingly become used for the construction of moral boundaries and collective identities. ${ }^{1}$

The first British Holocaust Memorial Day (HMD) took place January 27 2001. This followed the Stockholm International Forum in 2000, at the end of which representatives from 46 governments around the world signed a declaration committing to preserve the memory of those who were murdered in the Holocaust. The creation of Britain's HMD generated a swathe of historiography, comment and analysis from both academic and

\footnotetext{
${ }^{1}$ Tim Cole, Selling the Holocaust: From Auschwitz to Schindler, How History is bought, packaged and sold, (New York: Routledge, 2000); Russ Poole, Misremembering the Holocaust: Universal Symbol, Nationalist Icon or Moral Kitsch? in Yifat Gutman, Adam D. Brown, and Amy Sodaro, (eds.) Memory and the Future: Transnational Politics, Ethics and Society, (New York: Palgrave Macmillan, 2010), pp.31-49.
} 
journalistic sources. ${ }^{2}$ This literature suggested that HMD was born of, and reflects, a various range of sometimes competing national, international and transnational developments, including: the globalisation of Holocaust memory; the post- Cold War establishment of the Holocaust as a foundational European 'lieu de mémoire'; a salve for past inaction in the face of genocide; a 'Blairite' rhetorical tool to justify military 'humanitarian interventions' to ward off ostensible current/future genocides; in addition to short- and long-term domestic interests in politics and the commemorative industries.

It is notable that, in charting (that is, arguing for) these national, international and transnational interpretations, a great deal of commentary and analysis of HMD is offered from the first-hand perspective of academics writing about large scale public memorial or museum projects. There is, in contrast, very little published material that examines smallscale public participation with HMD, including but not limited to understandings of the aims of $\mathrm{HMD}$, what motivates the engagement of ordinary people with HMD and why, in particular, people get involved in organising their own commemorative activities. ${ }^{3}$

\footnotetext{
${ }^{2}$ See Larissa Allwork, Holocaust Remembrance between the National and the Transnational: The Stockholm International Forum and the First Decade of the International Task Force (London: Bloomsbury Academic, 2015).

${ }^{3}$ One significant exception is Will Eadson, Sarah Pearson, Mike Foden, Elizabeth Sanderson and Nadia Bashir, Holocaust Memorial Day Impact Study: Final Report, (Sheffield: Centre for Regional Economic and Social Research (CRESR) Sheffield Hallam University, 2015). For this impact study, researchers surveyed hundreds of HMD activity organisers and participants between November 2013 and October 2015, to assess "the extent to which HMD impacts on people's knowledge, attitudes and actions" Eadson et al, p.5.
} 
The Holocaust Memorial Day Trust (HMDT) organises free workshops across the UK for people interested in organising an activity to mark Holocaust Memorial Day. These workshops are designed to help attendees gain a better understanding of HMD and how to plan and manage activities meaningful for their audiences. In the winter of 2015 I attended three of these workshops (in London, Leicester and Sheffield) as a participant observer, and afterwards I interviewed the workshop facilitators and representatives of the HMDT and a self-selected number of workshop attendees. I asked these attendees questions relating to the workshop, their views on commemoration in general, and some more specific issues relating to the commemoration of HMD.

In another article ${ }^{4}$ I have examined the ways that HMD interpellates ordinary people, calling on them to join the norm $\operatorname{circle}^{5}$ of those committed to commemorating the Holocaust and subsequent genocides. According to Judith Butler, Althusser's "doctrine of interpellation appears to presuppose a prior and unelaborated doctrine of conscience" ${ }^{6}$ That is, "Conscience is fundamental to the production and regulation of the citizen-subject,

\footnotetext{
${ }^{4}$ John E Richardson, “Making memory makers: Interpellation, norm circles and Holocaust Memorial Day Trust workshops", Memory Studies (forthcoming)

${ }^{5}$ For a discussion of the concept of the "norm circle" see: Dave Elder-Vass, The Causal Power of Social Structures, (Cambridge: Cambridge University Press, 2010); Dave Elder-Vass, The Reality of Social Construction. Cambridge: Cambridge University Press, 2012); Dave Elder-Vass, "Collective Intentionality and Causal Powers", Journal of Social Ontology vol. 1 no. 2 (2015): pp.251-269.

${ }^{6}$ Judith Butler, "Conscience Doth Make Subjects of Us All", Yale French Studies, No. 88 (1995): pp. 6-26, p.8
} 
for it is conscience that turns the individual around to make itself available" when hailed. ${ }^{7}$ In this article, I examine the interview data in relation to these issues, and consider what it is that motivates individual involvement in HMD commemoration.

\section{Holocaust Memorial Day in Britain}

Britain was slow in developing what Andy Pearce refers to as Holocaust consciousness. ${ }^{8}$ As late as the 1970s, "British scholarship on Nazi antisemitism and the Holocaust was still virtually non-existent [...having] been subsumed for much of the post-war period beneath a carefully nurtured narrative of Second World War heroism and moral superiority." ${ }^{9}$ The 1990s brought a series of inter-related developments which, dialectically and cumulatively, marked a turning point for Holocaust consciousness in Britain. ${ }^{10}$ In response to the campaign work of the Holocaust Educational Trust (HET, established 1988), the Holocaust was included in the History National Curriculum from the early 1990s, which, in turn, spurred a demand for quality teaching resources. In 1991 the Imperial War Museum held a

\footnotetext{
${ }^{7}$ Butler, "Conscience", p.13

${ }^{8}$ Andy Pearce, "The Development of Holocaust Consciousness in Contemporary Britain, 1979-2001", Holocaust Studies: A Journal of Culture and History, vol. 14 no. 2 (2008): pp.7194; Andy Pearce, Holocaust consciousness in contemporary Britain, (London: Routledge, 2014).

${ }^{9}$ Pearce, "The Development of Holocaust Consciousness", p.73

${ }^{10}$ Sharon Macdonald, "Commemorating the Holocaust: Reconfiguring National Identity in the Twenty-First Century", in Jo Littler and Roshi Naidoo (eds.) The Politics of Heritage: The Legacies of 'Race', (Oxon: Routledge, 2005) pp.49-68; Pearce, Holocaust consciousness
} 
small exhibition The Relief of Belsen 1945, and then in 1995 Belsen 50 Years On, leading them to decide to establish a permanent Holocaust exhibition. Britain's first Holocaust museum, the privately funded Beth Shalom (now named the National Holocaust Centre and Museum), was opened in Nottingham in 1995. In 1999, a bill proposing "a day to learn about and remember the Holocaust" was introduced to the House of Commons by the Labour MP Andrew Dismore, following a visit to Auschwitz organized by the HET. And on January 26 2000, following the Stockholm International Forum, Robin Cook, then-British Foreign Secretary, announced the government's plans to initiate a Holocaust Memorial Day (HMD) on January 27, the day the Red Army liberated Auschwitz.

From its inception, the stated aim of the national HMD was "to move from the past to the present, from the particular to the universal. The stories of individuals and families will be used so that the fate of the Jews and other 'targets' of Nazi racial-biological politics can be personalized and the catastrophe perceived as a human event."11 As Cesarani reminds us, HMD primarily exists for didactic purposes; it is aimed, above all, "as an educational event". ${ }^{12}$ The first British HMD took place in 2001, with the main ceremony taking place at Westminster Central Hall and televised live on the BBC to around 1.5 million viewers. A capacity 2,000 audience of the three main political parties, cultural figures, 200

${ }^{11}$ David Cesarani, "Seizing the Day: Why Britain Will Benefit from Holocaust Memorial Day", Patterns of Prejudice, vol. 34 no. 4 (2000): pp.61-66, p.63

12 David Cesarani, "Does the Singularity of the Holocaust make it Incomparable and Inoperative for Commemorating, Studying and Preventing Genocide? Britain's Holocaust Memorial Day as a Case Study", The Journal of Holocaust Education, vol. 10 no. 2 (2001): pp.40-56, p.40 
Holocaust survivors and representatives of the wider Jewish communities were present, and Prime Minister Tony Blair gave the keynote speech.

In general, HMD enables Her Majesty's Government to advance the argument that their "priorities are strictly and honestly for the good of humankind." ${ }^{13}$ However, the sense, for some critical scholars, is that the government 'does commemoration' for performative rather than ethical reasons. ${ }^{14}$ On announcing HMD, Britain's then-Home Secretary Jack Straw declared: "Our aim in the twenty-first century must be to work towards a tolerant and diverse society which is based upon the notions of universal dignity and equal rights and responsibilities for all citizens. The Holocaust Memorial Day is a symbol of this". ${ }^{15}$ The noteworthy phrase in his speech was, of course, "for all citizens" - non-citizens are not afforded "universal dignity and equal rights" in Britain. It is this exception that enabled Jack Straw, six-weeks later, to lobby the UN, demanding "a complete overhaul of the United Nations Convention on refugees in a bid to stem the tide of refugees entering Britain" ${ }^{16}$ On this point, Kushner ruefully observed "the genuine refugee of popular mentality hardly exists in the here and now but is firmly, and of course safely, located in the past, where numbers are no longer a problem and action irrelevant. The ideal genuine refugee of the past should be part of a self-contained narrative in which members of a deserving minority

\footnotetext{
${ }^{13}$ Marc Levene, "Britain's holocaust memorial day: A case of post-cold war wish-fulfillment, or brazen hypocrisy?" Human Rights Review, vol. 7 no. 3 (2006): pp.26-59, p.51.

${ }^{14}$ Dan Stone, "Day of Remembrance or Day of Forgetting? Or, Why Britain Does Not Need a Holocaust Memorial Day", Patterns of Prejudice, vol. 34 no. 4 (2000): pp.53-59.

${ }^{15}$ Quoted in Levene, "Britain's holocaust memorial day” p.26

16 'Straw in bid to stem asylum', The Times, March 2, 2000
} 
persecuted by an evil regime... find refuge in another country to which they contribute generously, productively and with intense gratitude." ${ }^{17}$

Critics of HMD maintain that events and processes that destabilize national narratives of British decency are absent from the official national Commemorative Ceremony of HMD. For example, "the proud British tradition of taking in refugees", ritually invoked by politicians, is one such "myth. And one of the cornerstones of the myth is the remarkably persistent claim that this country did all it could to aid Jews trying to escape from Nazi persecution." ${ }^{18}$ Examples of this in politicians' speeches are not difficult to find David Blunkett's mendacious speech at the 2002 national HMD ceremony springs immediately to mind. ${ }^{19}$ However, we need to remember that politicians are not the only social actors who commemorate HMD. Many academic critiques of HMD are, at heart, criticisms of government policy (and discrepancies between government words and actions)

${ }^{17}$ Tony Kushner, "Meaning nothing but good: ethics, history and asylum-seeker phobia in Britain", Patterns of Prejudice, vol. 37 no. 3 (2003): pp.257-276, p.266

${ }^{18}$ Louise London, "Whitehall and the Refugees: The 1930s and the 1990s", Patterns of Prejudice, vol. 34 no. 3 (2000): pp.17-26, p.18

${ }^{19}$ At the 2002 national HMD ceremony, David Blunkett, then the Home Secretary, claimed: "the lesson of today is to accept our duty, our responsibility, our humanity, in offering a welcome home, a safe haven to those fleeing death and persecution. Today, we pledge to act." This was uttered at a time of sustained vilification of refugees and asylum seekers in British politics, and increasingly restrictive, increasingly unwelcoming, measures by the British government designed to deter those "fleeing death and persecution" to seek refuge in Britain. 
and, as such, they do not engage with the wide variety of people who are involved with organising or attending these initiatives. Cesarani took issue with Stone's pre-emptive criticisms of HMD, pointing to the success of a variety of Holocaust museum exhibits, the success of the National Holocaust Centre in Nottingham and the "memory-fest" of books, TV and radio programmes and newspaper reports that marked the $60^{\text {th }}$ anniversary of the Battle of Britain. ${ }^{20}$ In short: "the British are very good at remembering. ${ }^{21}$ Cesarani argued that the persistence of "memory from below" - of "Holocaust survivors, former refugees, Jewish ex-servicemen and others" - "means that the government cannot simply shape memory as it wishes and for its own purposes." ${ }^{22}$ Later, Cesarani was more critical of both Britain and its historic record, and arguments from academics that HMD should primarily attend to the "belief systems and circumstances [which] allowed the idea of genocide to be accepted and acted upon." ${ }^{23}$ Speaking on "Britain, the Holocaust and its Legacy", he noted:

It would be reassuring to think that we need only look at the perpetrators to draw lessons about the origins of evil-doing. But, sadly, we can learn a lot from British responses to the Nazi rampage against civil liberties, human rights, and the lives of millions of innocents... The Government preferred to accept fit and strong refugees

\footnotetext{
${ }^{20}$ Ceserani "Seizing the day"; Stone, “Day of Remembrance or Day of Forgetting?"

${ }^{21}$ Ceserani "Seizing the day", p.62

${ }^{22}$ Ceserani "Seizing the day", pp.64-65

${ }^{23}$ Donald Bloxham, "Britain's Holocaust Memorial Days: Reshaping the past in the service of the present", Immigrants \& Minorities, vol. 21 no. 1-2 (2002): pp.41-62, p.47
} 
who, after a brief while, would get employment in other countries. The old rarely got in; children were saved, but their parents were rejected. ${ }^{24}$

And specifically, on the ways that the past is invoked and used in the present, he argued:

You might think that we have nothing to learn from the extreme and unusual circumstances of war and occupation, but even here we need to engage in reflection, if only because the British people tend to have a rather self-satisfied perception of the Second World War as unambiguously a 'good' war from which this country emerged triumphant and morally vindicated. As always, the historical record is more complicated than that. While there is more to be proud of than to regret, there were shameful episodes which have tended to be swept under the carpet of historical forgetting. ${ }^{25}$

It is the possibility of "memory from below" and its relationship to more reflexive (and, possibly, critical) forms of British Holocaust consciousness that forms the basis of my research on HMD. Anecdotally, I have attended HMD commemorative events that made explicit comparison between Kindertransport refugees and Syrian children currently denied refuge in Britain, in order to criticise government policy; I have read transcripts from other HMD events that expounded on Browning's 'Ordinary Men' thesis, or which quoted from Mein Kampf in order to better understand the nature of Nazism.

${ }^{24}$ David Cesarani, "Britain, the Holocaust and its Legacy: the theme for Holocaust Memorial Day, 2002", http://www.hmd.org.uk/resources/theme-papers (2002) [accessed on 4 February 2013], p.1

${ }^{25}$ Cesarani, "Britain, the Holocaust and its Legacy", p.2 
I am particularly interested in the meteoric rise in commemoration aside from the national commemoration ceremony, and the ways that ordinary people understand Holocaust commemoration. 7,700 activities took place across the UK for HMD 2017, in workplaces, schools, universities, local government buildings and civic spaces, a significant increase on the 5,590 activities that took place in 2016 and the 3,600 activities that marked HMD 2015. Organising HMD commemorative events is increasingly taken on by institutions, charities and individuals in civil society, potentially decentring the focus previously given to the national HMD commemorative event. Clearly, given such a large number of diverse commemorative activities, it is impossible to be able to summarise their contents in anything other than broad brush strokes. ${ }^{26}$ However, it seems reasonable to assume that those organising an event do so because they wish to commemorate in a different way, and/or a more active way, than attending an already established event or watching a ceremony on television. These are individuals who move from what Kansteiner would term "memory consumers" towards acting as memory makers ${ }^{27}$ - they choose to organise the commemoration of HMD themselves and so contribute to collective knowledge of the Holocaust and subsequent genocides in parallel to those offered by, or attended by, representatives of local and national government. This article is a step towards understanding people's motivation for organising a HMD commemoration; in later articles, I will analyse some of the rhetorical contents of these diverse local events.

\footnotetext{
${ }^{26}$ Though see the Annual Reviews of HMD, published by the HMDT every year since 2008 : http://hmd.org.uk/page/annual-review [accessed 26 May 2017]

${ }^{27}$ Wulf Kansteiner, "Finding Meaning in Memory: A Methodological Critique of Collective Memory Studies", History and Theory, vol. 41 no. 2 (2002): pp.179-197.
} 


\section{Method \& data}

This article is part of a wider project aimed at analysing linguistic and semiotic processes employed in the commemoration of HMD, their potential for shaping the understanding of mass audiences and the ways that the commemoration of HMD has changed since 2002. My work employs a discourse analytic approach to a multi-sited ethnography, ${ }^{28}$ drawing in $^{2}$ particular on the Discourse-Historical Approach (DHA) to Critical Discourse Analysis, ${ }^{29}$ in

${ }^{28}$ George E. Marcus, Ethnography through Thick and Thin, (Princeton: Princeton University Press, 1998).

${ }^{29}$ Hannes Heer, Walter Manoschek, Alexander Pollak and Ruth Wodak, (eds.) The Discursive Construction of History: Remembering the Wehrmacht's War of Annihilation, (Houndmills: Palgrave, 2008); Michel Krzyżanowski, The Discursive Construction of European Identities: A Multilevel Approach to Discourse and Identity in the Transforming European Union, (Frankfurt am Main: Peter Lang, 2010); Michal Krzyżanowski, (ed.) “Ethnography and Critical Discourse Analysis" (Special Issue), Critical Discourse Studies vol. 8 no. 4 (2011): pp.231-309; Michal Krzyżanowski, "Ethnography and Critical Discourse Studies", in John Flowerdew and John E. Richardson (eds.) The Routledge Handbook of Critical Discourse Studies, (Routledge: London, 2018); Michal Krzyżanowski and Florian Oberhuber, (Un)Doing Europe: Discourses and Practices of Negotiating the EU Constitution, (Brussels: PIE-Peter Lang, 2007); Peter Muntigl, Gilbert Weiss and Ruth Wodak, European Union Discourses on Un/Employment: An interdisciplinary approach to employment policy making and organizational change, (Amsterdam: John Benjamins, 2000); Ruth Wodak, Disorders of Discourse, (London: 
order to make sense of (1) the field of remembrance and its genres (e.g. ceremonies, speeches, stories, testimony, music, minutes of silence, etc.) and (2) the ways that they reflect the complex interplay between collective remembering ${ }^{30}$ and social and historic contexts. My analysis is informed by the perspective of critical ethnography, ${ }^{31}$ going beyond asking 'what is', typical of conventional ethnography, to also ask 'what could be?', reflecting on the discursive process of choosing between conceptual and political alternatives.

I am currently working with data from three sites: ethnographic participant observation of three HMDT workshops; interviews with participants and organisers of all these workshops; and an auto-ethnographic account of the HMD event I organised. I maintain that the current literature on the British HMD is deficient, since it ignores the involvement, and motivations, of non-political actors in the practices of Holocaust commemoration. This article examines the interview data, which were all recorded and transcribed verbatim. I interviewed 6 people from HMDT: the chief executive, Outreach Officer, two regional support workers and two 'youth champions'. ${ }^{32} \mathrm{I}$ also interviewed 8

Longman, 1996); Ruth Wodak, Rudolf de Cillia, Martin Reisigl and Karin Liebhart, The Discursive Construction of National Identity, (Edinburgh: Edinburgh University Press, 1999).

${ }^{30}$ James V. Wertsch, Voices of Collective Remembering, (Cambridge: Cambridge University Press, 2002).

31 John M. Thomas, Doing Critical Ethnography, (Newbury Park/London: Sage, 1993).

${ }^{32}$ The HMDT Youth Champion Programme "empowers young people to take action for Holocaust Memorial Day (HMD) through organising their own events and raising awareness of HMD in their community and among other young people". It is open to anyone aged 
participants who had attended workshops in London, Sheffield and Leicester. I asked workshop participants questions covering three main areas: 'what brought them to the workshop' (which then covered their histories of commemoration and how long they had commemorated HMD); their views on commemoration in general; and more specific issues relating to themes and topics of commemorating HMD, both in general and in relation to the theme of HMD 2016, 'Don't Stand By'. Interviewees from HMDT were asked similar questions, but instead of 'what brought them to the workshop' I asked them about their work for HMDT, both in terms of their duties and responsibilities and what they hope to achieve through their work. The interviews ranged from 24 minutes to 50 minutes; together, they total 7 hours 58 minutes, and average 39 minutes each. In this article, these interviewees are numbered (HMDT1, HMDT2, London1, London2, etc), to ensure anonymity.

\section{What motivates people's engagement with HMD?}

I contend that the people who commemorate HMD should be viewed as a norm circle. ${ }^{33}$ Norm circles are "groups of people who are committed to endorsing and enforcing specific norms." ${ }^{34}$ More specifically, norm circles "are social entities with people as their parts, and because of the ways in which the members of such groups interact (a mechanism) they have

fourteen to 24 interested in organising an activity as part of HMD. Quoted from:

http://hmd.org.uk/page/youth-champions [accessed 9 November 2016]

${ }^{33}$ Richardson, "Making memory makers"

${ }^{34}$ Elder-Vass, Reality of Social Construction, pp.201-202 
the causal power to produce a tendency in individuals to follow standardised practices". ${ }^{35}$ Elder-Vass maintains that people are "agentic subjects in the sense that they can make decisions that affect their actions." ${ }^{36}$ Whilst such decisions are constrained and shaped by indeed, they index - a number of individual and social factors, they are not wholly determined by these factors. So, when we make decisions, "those decisions are influenced by beliefs and dispositions that are themselves the product of their past experience, including their past social experience... the product of an embodied history of relating to the world." ${ }^{37}$ Similarly, actions and events are not the result of single causal powers acting upon us in a deterministic way. Causal powers instead "operate as tendencies. Any given causal power has a tendency to produce a certain sort of outcome but these tendencies may be frustrated when causal powers with conflicting tendencies interact with them." ${ }^{\prime 38}$ It is for this reason, perhaps, that politicians (and, if we are honest, many of us) do not always maintain the commitment to values expressed at HMD commemorations unfailingly through the rest of the year.

The theory of norm circles is not static. Elder-Vass acknowledges that competition exists between different incompatible norms ${ }^{39}$; that new norms can develop in line with new social structures; and the power of one norm circle can increase, with attendant implications regarding the pervasiveness with which its norms are endorsed and enforced.

\footnotetext{
${ }^{35}$ Elder-Vass, Reality of Social Construction, pp.22-23

${ }^{36}$ Elder-Vass, Reality of Social Construction, p.201

37 Ibid; see also Richardson "Making memory makers"

${ }^{38}$ Elder-Vass, Reality of Social Construction, p.16

${ }^{39}$ Elder-Vass, Causal Power
} 
Indeed, power is an integral feature of the theory, wherein "the power to generate a tendency in individuals to observe a norm is an emergent causal power of the norm circle as a whole." 40

Epideictic rhetoric, such as that produced and consumed at commemorative events, is one way in which norm circles are discursively invoked and recreated. Epideictic rhetoric invokes praise and blame and, implicitly, the values upon which such positive and negative evaluations are based. As such, epideictic rhetoric it is directed towards strengthening "the disposition towards action by increasing adherence to the values it lauds." ${ }^{41}$ At the heart of the commemorative practices of HMD is an understanding of the Holocaust as a catastrophe and a great affront to Our values; detailing the circumstances and consequences of the Holocaust acts to revivify Our commitment to the values that it so clearly transgressed. Holocaust commemoration thereby functions as a form of prospective memory: in the future, if our values are threatened, we need to remember to do something about it. Whilst this might appear indisputable, experience of wars and genocides since World War II tells us otherwise. Unlike deliberative or forensic rhetorics, which advocate political or legal decision making, "the argumentation in epideictic discourse sets to increase the intensity of adherence to certain values, which might not be contested when considered on their own but may nevertheless not prevail against other values that might come into contact with

\footnotetext{
${ }^{40}$ Elder-Vass, Reality of Social Construction, p.27; see also Elder-Vass “Collective intentionality"

41 Chaim Perelman and Lucie Olbrechts-Tyteca, The new rhetoric: A treatise on argumentation, (Notre Dame: University of Notre Dame Press, 1969), p.50
} 
them." ${ }^{42}$ In other words, epideictic rhetoric, like that in HMD ceremonies, can be viewed as a response to the demands that uncertainty of the future "places upon one's conscience." Norm circles act "through the individuals who are their members", ${ }^{44}$ and in ways that are consistent. However, that doesn't mean that there are not different ethical rationales for following a particular norm - meaning that, in the case of this research, people offer different reasons for endorsing their shared norm of commemorating HMD. In the sections below, I explore three groupings of responses from my interviewees in order to examine their motivation for commemorating HMD. I discuss the views of members of the public and representatives of HMDT, not in order to compare/contrast them, but rather to examine the ways that they resonate with each other and reflect shared normative understandings of Holocaust commemoration.

\section{Aims of HMD: listening, learning, acting}

Remembrance and commemoration simultaneously invoke the past, present and future. They entail communication processes wherein people, events and stories of the past are recalled, retold and recontextualized in the present, often (politically) instrumentalised to try to ensure that history doesn't 'repeat itself' in the future. ${ }^{45}$ For many of my

\footnotetext{
${ }^{42}$ Perelman and Olbrechts-Tyteca, New rhetoric

${ }^{43}$ Ilon Lauer, "Epideictic Rhetoric", Communication Research Trends vol. 34 no. 2 (2015): pp.4-18, p.12

${ }^{44}$ Elder-Vass, Reality of Social Construction, p.202

45 Bernhard Forchtner, Lessons from the Past? Memory, Narrativity and Subjectivity, (London: Palgrave, 2016).
} 
interviewees, this futurity of commemoration was best achieved through the educational function of HMD:

London2: the mission is really just to extend and increase people's education and understanding of what went on... and then it's all the lessons about how to avoid it happening again, would be the top of the tree in priority terms.

Here, education isn't presented as central to "the mission" of HMD, it is the mission. As Bickford and Sadaro suggest, "this rationale relies (implicitly) on a theory of change concerning democratic learning and the very modern belief that an accumulation of knowledge can help to shape a better future." ${ }^{46}$ A secondary aim of HMD is syntactically implied, through the conjunction "and then it's...", but given that this second aim is framed as "lessons about how to avoid it happening again" it is subordinated to the primary didactic purpose of HMD.

Recently, work within memory studies has begun to acknowledge and examine the ways that commemorative work in the present looks to the past to shape the future. ${ }^{47}$ As Cesarani demonstrates, this shuttling between past, present and future (or, in Aristotelian rhetorical terms, between the special topics of the just/unjust, praise/censure and the

${ }^{46}$ Louis Bickford and Amy Sodaro (2010) "Remembering Yesterday to Protect Tomorrow: The Internationalisation of a New Commemorative Paradigm", in Yifat Gutman, Adam D. Brown, and Amy Sodaro, (eds.) Memory and the Future: Transnational Politics, Ethics and Society, (New York: Palgrave Macmillan, 2010), pp.66-86, p.68

47 Yifat Gutman, Adam D. Brown, and Amy Sodaro, (eds.) Memory and the Future: Transnational Politics, Ethics and Society, (New York: Palgrave Macmillan, 2010). 
beneficial/detrimental) has existed in HMD from its inception. ${ }^{48}$ The following interviewee offered exactly such an argument:

HMDT1: Holocaust Memorial Day is a very dynamic day. The key purpose of it is [pause] it's a dual purpose. It's to reflect on the past and commemorate the past, and it's to take steps to create a safer, better future. It's not a static day solely of reflection and remembrance. It's absolutely about that dynamism between what happens when you think about the past and reflect on it and think well, what does that mean for me today? What are my responsibilities and what can I do? And it creates that opportunity to do something.

Here, the Trust staff member suggests that HMD should ask questions of us - what does it (the past) mean for me today? what can I do (now and into the future)? These questions, and the processes through which we pose these questions to ourselves, create opportunities "to do something". That is, for this interviewee, HMD is not characterised by (or at least not solely by) an inward or contemplative response to the past, but rather it requires her to translate such reflection into material action. Such a view of the overall function of HMD was shared by many of those I interviewed - particularly given that the theme of HMD in the year I conducted my interviews was Don't Stand By, which was interpreted as a direct call to moral political intervention. ${ }^{49}$

My interviewees identified Jewish testimony, of both survivors and those who were killed, as a key feature of HMD. The inclusion and attention given to such testimony, over

\footnotetext{
${ }^{48}$ Cesarani, "Singularity of the Holocaust"

${ }^{49}$ See Richardson "Making Memory Makers"
} 
and above critical attention given to perpetrators, was identified as central to the symbolic and semantic meaning of the day. For example:

HMDT5: I think it's important to almost legitimise their stories. For some of the survivors especially it's about being heard, almost like not being forgotten... I think it's important that it's about taking the past, remembering the past, commemorating the past and giving legitimacy to those stories, but taking it forward into our future and our lives.

This interviewee again stresses the interplay between past and future invoked, and indexed, in HMD. In her account, such testimony performs several functions: first, it functions as a guard against the "mortality of memory" ${ }^{50}$ by reminding people (or perhaps informing them, if they were unaware) this happened, it happened to me and people like me. Second, and in part paradoxically, testimony of survivors is included in order to recognise and memorialize the dead, and so to emphasise that genocides are not narratives of survival. In other words, the presence of the survivor, the testimony of the survivor, simultaneously indexes the absence of the victims who did not survive. Third, victim testimony functions as a form of auscultation - that is, the act of listening is used as an aid to diagnosis and treatment of social and political ills, which can then be taken up and addressed in the future.

Other interviewees had more specific ideas about the aims of HMD, and what they hope to achieve through commemoration. For example:

${ }^{50}$ Douwe Draaisma, Metaphors of Memory: A History of Ideas and the Mind, (Cambridge: Cambridge University Press, 2000). 
London2: One of the themes of Holocaust Memorial Day is trying to relate the story of ordinary Jewish life. This is a life of thanks... it's all part of trying to show Jews as other than victims. Which is an important objective, [of] Holocaust Memorial Day.

Commemorating the murder and destruction of Jewish communities were prime motivations of many of my interviewees (see below). However, the point made in the above extract was an unusual one, given the way that the interviewee simultaneously invokes the catastrophe of the Shoah whilst stating it is vital to represent and view "Jews as other than victims". Here then, my interviewee repeats, almost precisely, Philip Friedman's argument, addressed to the World Congress of Jewish Studies: "What we need is a history of the Jewish people during the period of Nazi rule in which the central role is to be played by The Jewish People, not only as victims of a tragedy, but also as the bearer of a communal existence with all the manifold and numerous aspects involved." ${ }^{51}$ This view, reflected most clearly in the 'Israeli school' of Holocaust research," "emphasizes the Jews as a living

51 Quoted in Amos Goldberg, "The History of the Jews in the Ghettos: A Cultural Perspective", in Dan Stone (ed.) The Holocaust and Historical Methodology, (New York/London: Berghahn, 2012), pp.79-100, p.83

${ }^{52}$ Yehuda Bauer, Rethinking the Holocaust (New Haven: Yale University Press, 2002); Yehuda Bauer, The Death of the Shtetl (New Haven: Yale University Press, 2010); Israel Gutman, Fighters Among the Ruins: The Story of Jewish Heroism During World War II, (Washington DC: Bnai Brith Books, 1988); Dan Michman, Holocaust Historiography: A Jewish Perspective, (London: Vallentine Mitchell, 2003). 
collective and views antisemitism as an existential datum of European culture." ${ }^{53}$ For example, Krakowski's Chronological Table of Events between 1933-1945 summarises those thirteen years in three columns, in turn labelled: "International Events and Events in the Third Reich"; "The War Against the Jews"; and "Jewish Activities", both against and in parallel to this persecution. ${ }^{54}$ The identical size of the three columns in Krakowski's table indicates that each is equally necessary to study and understand.

Whilst traditional historians may dismiss the very idea that historical insight is possible without dedicated application of historical method as outlined by Lord Acton, ${ }^{55}$ the extract from my interview with London2 demonstrates that the line between 'lay' and 'professional' understandings of the past is perhaps less clearly demarcated than some would like to admit.

Non-hypocritical remembrance

${ }^{53}$ Dan Michman, "Is there an 'Israeli School' of Holocaust Research?" in David Bankier and Dan Michman (eds.) Holocaust Historiography in Context: Emergences, Challenges, Polemics and Achievements, (Jerusalem: Yad Vashem / New York: Berghahn Books, 2008), pp.37-65, p.64.

${ }^{54}$ Shmuel Krakowski, “Chronological Table of Events, 1933-1945”, in Yisrael Gutman and Livia Rothkirchen (eds.) The Catastrophe of European Jewry: antecedents, history, reflections, (Jerusalem: Yad Vashem, 1976), pp.705-738.

55 For a summary and critique see Dan Stone, "Introduction", in Dan Stone (ed.) The Holocaust and Historical Methodology, (New York/London: Berghahn, 2012), pp.1-19. 
Several interviewees argued that it is hypocritical to commemorate HMD and not also oppose acts of military aggression, particularly Britain's contemporary involvement in war. Two interviewees drew a specific comparison between HMD and the message (or lesson) of the British Armistice Day commemoration:

Sheffield2: There's all these people marching on November 11th and say how terrible it is that people died... but are preparing to go off and fight a war somewhere else. That to me seems a very hypocritical position and we have to make sure that HMD is something that says, 'We're against the horrors that took place in the past and we don't stand by idly while we see new horrors being created today'. HMDT5: For me I think it's all very well marking something, but what are you doing by marking it? ... in the same way as Remembrance Day, you have to take a lesson from it. Otherwise you can say as many times as you want 'never again, never again', but that becomes a meaningless thing to say when you are still doing it.

For both these people, HMD demands that people act - and not just on the 27 January, but in their lives through the remainder of the year, to oppose the horrors of warfare. Whilst they appear to disagree slightly on the meanings that people take from Remembrance Day, both clearly feel that 'never again' can signal opposition to the destruction of human life in (past/present) warfare and not simply in relation to genocide. Those who mourn the deaths of military personnel and civilians in past conflicts, and yet are not opposed to warfare now, are accused of misunderstanding the lessons of commemoration. Indeed, for Sheffield2, Armistice Day Remembrance Day in the UK stands as an abject example of how not to commemorate, and one that HMD should ensure it does not replicate.

In addition, both interviewees shine the spotlight of this critique onto the national self; specifically, in both, there is a sense that the target of this criticism is the UK 
government. Looking at the first extract: there are only so many people who march on Remembrance Day, have speaking rights ("say[ing] how terrible it is that people died") and also are in a position to be "preparing to go off and fight a war somewhere else"; he can only be imagining members of the government or the military. In the second extract, the accusation is more direct: claiming that you are dedicated to ensuring 'never again' is meaningless "when you are still doing it". Whilst I do not have empirical evidence of what was said in the events organised by these two interviewees, having attended other HMD events where the military policies of the British government in Libya and Syria were criticised on both moral and consequentialist grounds, it is possible that aspects of this nonhypocritical remembrance were vocalised at their events.

These criticisms of governmental and military mendacity appear to be a key way in which activity organisers and participants of HMD enforce the boundaries of the norm circle to which they belong: although some people might claim to be dedicated to applying the lessons of HMD, they are in fact behaving inconsistently.

\section{Conscience}

In a similar vein, other interviewees declared that commemorating Holocaust Memorial Day fitted with their sense of 'doing the right thing' in society. For some, this was expressed in an open and indefinite sense:

London4: It's the old adage, you know, even if you're standing alone, still stand, you know. If you've got those convictions then you have to do what you can do.... I was brought up to just, to believe, you know, that you just, you simply, you do the right thing. 
Here, "I was brought up to [do X]" functions to position particular actions, in the present, as expressions of a recurring and consistent narrative of the self. However, it also achieves a little more than this. Whereas script formulations represent actions and events in terms of their predictability - as always or repeatedly or never taking place - living (unfailingly) in accordance with 'my upbringing' functions as an explanation of this consistency. That is, he was inculcated into a norm circle by his parents, and his membership of this norm circle explains his (consistent) actions. My interviewee is notably vague here about what these convictions are, other than that he is compelled to "do the right thing" and that this includes commemorating HMD (though later in the interview he spoke of his Christian faith). His conscience acts as an imperative, directing the actions of himself and other people with convictions - they "have to do" what they can, to "do the right thing". His view, therefore, accords exactly with Butler's observation regarding interpellation, that "conscience doth make subjects of us all." ${ }^{56}$

If this first interviewee represents his commemorative activities as being symptomatic of his convictions, others explain their actions using a more consequentialist line of argument:

Sheffield2: Within my own teaching, I've tried to raise issues around care and consideration for others... that whole care and consideration for others, for me, links in with [pause] the reason why we care and consider for others today is we see the horrors that history shows us can come about if we don't have an empathy for people from other cultures and other points of view.... I think that's something that has been emphasised over the last few years by the growth of organisations in most

\footnotetext{
${ }^{56}$ Butler, "Conscience"
} 
European countries, that actually model themselves on the Nazis. I think that's very worrying.

Here, the interviewee starts by stating that his commemoration is motivated by, and reflects, his commitment to the "care and consideration for others". However, for him, this "care and consideration for others" is not simply an end in itself, but is rather motivated by his ethical and political goals to prevent reactionary political projects and the horrors that they can generate in society. This motivation accords with the views of "social and political actors in the present" summarised in Bickford and Sodaro, "who hope that by confronting the past, they will be able to make real and concrete contributions to building a better future". ${ }^{57}$ Sheffield 2 refers to neo-Nazi parties across Europe, and later in the interview listed the German Pegida movement, Hungary's Jobbik and Greece's Golden Dawn parties as being of particular concern. What this interviewee sees as uniting these parties is their anti-humanism, their hostility towards those regarded as different, and their antipathy to basic democratic principles:

Sheffield2: So I think that part of the reason for having HMD as prominent as possible is to say: these organisations which are growing in Europe today, we've seen what their policies led to back in the thirties and forties, we should learn from history, and we should make sure that people realise that they aren't a solution to the troubles that people have.

It is, he argues, "a duty" to commemorate HMD, in part to voice opposition to this growing prominence of Europe's far- and extreme-right political parties, and their illiberal answers to contemporary social and political problems.

\footnotetext{
${ }^{57}$ Bickford and Sodaro "Remembering Yesterday", p.68
} 


\section{Jewish Identity}

The British HMD does not solely commemorate the murder of Jews during the Shoah; the victims of Nazi persecution (inter alia Roma and Sinti, Slavs, Homosexuals and political opponents) and four other subsequent genocides are also commemorated. However, for all of my Jewish interviewees, their Jewish identity and personal relationship to the catastrophe of the Holocaust played a large role in their motivation to organise commemorative activities. ${ }^{58}$

Jewish activity organisers are motivated to commemorate HMD by a range of personal factors, some general and some more specific and directly personal. London3, for example, attended the London workshop because of her identity as a Jewish survivor of the second generation. She explained that she had attended as an act of remembrance for her mother's family who were murdered in the Holocaust and, more specifically, to publicize and advocate for "what the Viennese call a 'stone of remembrance', you may know them as Stolpersteine" (London3). She had recently returned from a trip to Vienna, to lay a stone commemorating her mother's family, and she attended the workshop in London because she "wanted to find a way of getting information about the stones of remembrance out, because for me it's quite important that, you know, these people, like my mum... who lost family, who could do this and feel as much comfort as I felt" (London3). It may please her to know that other attendees I interviewed remembered speaking with her about this aim.

${ }^{58}$ See also Noah Benninga and Katrin Stoll, "Personal Engagement and the Study of the Holocaust: Redressing the Missed Conversation of the Past", Holocaust Studies: A Journal of Culture and History, vol. 20 no. 1-2 (2014): pp.1-16. 
Without being prompted by me, another interviewee recalled speaking to "a lady who, I can't remember the name of, but basically there's... cobblestones if you like, placed outside the houses of people... So, you know, I had a couple of email conversations with her and I looked at the website" (London4).

Another interviewee, who attended the London workshop, had been involved in the commemoration of HMD since Autumn 2000. He had heard about HMD through a fringe meeting at his party's annual political conference, and had decided "I had to go to it because I was the only member of the City Council of [Anonymous City] with a direct link to the Holocaust, through both my parents being refugees, and I saw it as very important to promote this new enterprise and commemoration" (London2). Following this fringe party meeting he decided to organise a civic commemorative activity in his place of work:

London2: if I didn't do it, nobody would, because although at that stage there was one other councillor... who is actually of Jewish origin but not from the Holocaust generation but from the eighties and nineties. Neither of us are religiously Jewish for example. He was more junior in hierarchy anyway, so I felt if I didn't do anything then nothing would happen.

Here, the interviewee stresses his personal compulsion to do something, because he felt that if he didn't, it wouldn't happen, and to not commemorate HMD was self-evidently wrong. His Jewishness and that of the other councillor is mentioned in a way that simultaneously presents it as incidental and fundamental: he doesn't explicitly explain that they became involved in commemorating HMD because they were Jewish (the Jewishness of the second councillor is almost mentioned as an aside, "who is actually of Jewish origin..."); however, the only two people in his organisation who were sufficiently determined to commemorate HMD were Jewish (and one of these lacked the institutional 
authority). He clearly indicates that the commemoration of HMD absolutely needed to happen, and that if he "didn't do it, nobody would". This emphasises that, at that stage at least, (1) commemorating HMD was perceived as being a relatively marginal commitment, and (2) commemorating HMD was a commitment that required individual champions to bring it about.

Another interviewee told me he will typically commemorate HMD both in his work, as a teacher, and at local public commemorations:

John: And why is that then, can I ask? Why is it that you feel the need to commemorate both in your job and in your personal life?

London1: For me, I have - I come from a Jewish background. I know that some members of our family died in the Holocaust. Others were relocated and survived.

His answer doesn't directly address my question regarding the need he feels to commemorate more than once. However, a reason is inferable: for him, the scale of the tragedy of the Shoah, and his direct experience of family members being murdered (though he uses the intransitive verb 'die' rather than the transitive 'kill/murder'), means that one commemorative activity is insufficient. It may also be that the different commemorative activities allow him to perform different social/rhetorical functions: as teacher/speaker in his working life, directed at least in part by the constraints of the curriculum and expectations of scholarly dispassion; and for more personal, affective and individually directed reasons as an attendee/mourner in public commemorations. Specifically, engaging in commemorative activities outside of his working life allowed this interviewee to bring a religious dimension into his commemoration of HMD. In a segment of an interview that I found particularly moving, he stated his motivation as follows: 
London1: I've spoken to Jewish communities across many parts of the world who have lost the whole community, they've lost whole groups, and you know, they had nobody to say Kaddish, to say the prayer for thanksgivings gone, for His greatness in such terrible situations.... for a Jewish person not to have someone say Kaddish, it's a very sad thing to not be able to stand at the grave. And I suppose that's part of what I do as well in a small way.

John: You're saying Kaddish for the lost communities?

London1: For - yes, indeed, for lost communities... I do that because, as a Jewish person, I consider myself to be attached to those who've gone in the past. But I'm Jewish because of my background and because somebody was Jewish before me and consequently I am. I'm also Jewish, I believe, because of my choice of continuing faith. I don't think it's a lot to put on me because I suppose with the old saying of, you know, if not now, when? If not me, then who?

Following Althusser, a great deal has been written regarding interpellation and agency that is, whether, when we act in accordance with our conscience, this should be regarded as a choice or something more akin to a compulsion. In the extract above, this interviewee represents his commemorative activities, and specifically his decision to say Kaddish for the Jewish communities murdered during the Holocaust, in terms that imply a non-decision that is, his reciting Kaddish for the dead is somehow incumbent on him as a result of his "choice of continuing faith". However, if we were to simply view his actions in this way, observed as a matter of religious duty, it would lose some of the meaning and significance of his choice. Indeed, Jewish men are only obligated to recite Kaddish for deceased relatives, particularly their parents; the interviewee, in effect, positions himself as an adoptive son of all those who were murdered and, in so doing, takes it upon himself to recite the Kaddish. 
Deciding to say Kaddish for those to whom one is not related therefore transposes a familial obligation to an act of transnational reverence and respect for the wider Jewish community, and in particular for the communities lost.

However, the consequence of choosing to say Kaddish as an act of commemoration for the victims of the Shoah is also signified by the content of the prayer itself. Conventionally understood as a prayer for the dead, the Mourner's Kaddish does not mention death, nor make any reference to the deceased. It is, instead, a prayer about the value of life; it praises God's name, affirms God's justice and states that He is the creator and ruler of the world. Through offering praise of God, the mourner transforms the event of death into an act of life. In this way, London1's religious act of commemoration is very similar to the secular motivation of London2, quoted earlier in the article: to sanctify life, to remember the humanity of those who suffered and died, and to remember the ways that life goes on, even whilst standing in the long shadow of catastrophe.

\section{Conclusion}

This article has presented and analysed interview data collected as part of a wider project aimed at analysing British Holocaust Memorial Day commemoration. Since 2002, and particularly since the Holocaust Memorial Day Trust took responsibility for organising HMD in 2005 , there has been a meteoric rise in the number of people organising and attending events as part of HMD. I am interested in how we can account for such a rise, and the mechanics underwriting this increase - in other words, what motivates people to get involved, and what forms does this involvement take. Using the work of Dave Elder-Vass I contend that HMD can be treated as a norm circle - that is, as a group of people who are committed to endorsing and enforcing the norm of commemoration of the Holocaust and 
subsequent genocides. In contrast to some of the more critical accounts of the political functions of HMD extant in the academic literature - inter alia, that HMD is an act of organised hypocrisy, celebrating Our welcoming of the refugees of the past whilst refugees of the present were being barred from Britain; or avowing 'Never Again' "while the UK, a state possessing weapons of mass destruction, enjoyed diplomatic relations with governments that systematically violated human rights and supplied arms to regimes that repressed ethnic and national minorities" ${ }^{59}$ - public engagement in HMD commemoration appears to be motivated by a genuinely felt need to act in accordance with personal and political conscience. HMD calls to people, interpellating them into the norm circle, through appealing to their sense of conscience. ${ }^{60}$ The influential power of conscience took several forms for my interviewees, but all presupposed a revulsion at the brutality and barbarism of genocide and crimes against humanity; a desire to commemorate and honour the humanity of the victims of genocide; and a deep concern for the suffering of others, in a world where violence and reactionary politics are still very much a reality.

The organisers of local HMD commemorative activities that I interviewed are aware of the national commemorative event, but tend to place their own activities in parallel with this event rather than in dialogue with it. Indeed, for some activity organisers, the involvement and input of the British government in the national commemoration was at odds with the lessons that they took from the Holocaust - most importantly to be

${ }^{59}$ David Cesarani, "Holocaust Memorial Day in Britain, History Today, vol. 52 no. 2 (February 2002) available at http://www.historytoday.com/david-cesarani/holocaust-memorial-daybritain [accessed 22 November 2016].

${ }^{60}$ Richardson, "Making memory makers" 
welcoming and accommodating to those in need (specifically refugees), to oppose intolerance and national chauvinism, and to oppose warfare. These dimensions of popular HMD commemoration, and specifically the extent to which the desire for 'non-hypocritical commemoration' contrasts with governmental rhetoric, demand further analysis and critical reflection.

\section{Acknowledgement}

This research was funded by a Leverhulme Trust Research Fellowship. I gratefully acknowledge this support. 